Typology of abuse and harassment in domestic work in Portugal

Maria da Conceição Figueiredo

Fátima Suleman

Maria do Carmo Botelho

Dezembro de 2015

WP n. ${ }^{\circ} 2015 / 18$

DOCUMENTO DE TRABALHO

WORKING PAPER

DINAMIP'CET

CENTRO DE ESTUDOS SOBRE A MUDANCA
SOCIOECONÓMICA E OTERRITÓIIO

ISCTE-IUL 


\title{
Typology of abuse and harassment in domestic work in Portugal
}

\author{
Maria da Conceição Figueiredo * \\ Fátima Suleman ** \\ Maria do Carmo Botelho ***
}

WP n. $\circ 2015 / 18$

DOI: $10.15847 /$ dinamiacet-iul.wp.2015.18

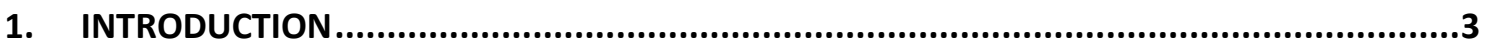

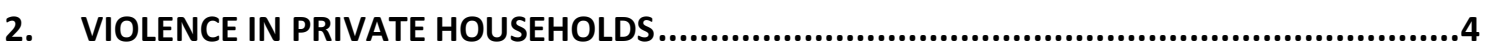

2.1 Abuse and harassment in domestic work …............................................................... 4

2.2 Abuse and harassment in domestic work in Portugal................................................. 6

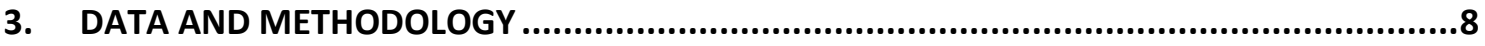

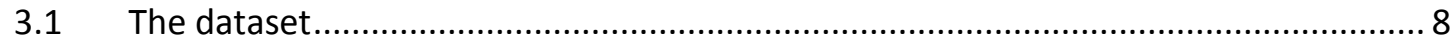

3.2 Constructing typologies: multiple correspondence and cluster analysis..................... 10

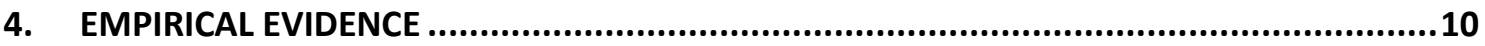

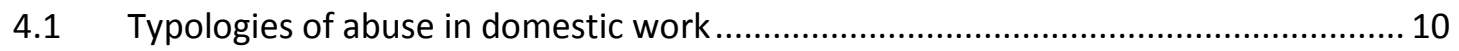

4.2 Domestic workers and job characteristics ................................................................. 13

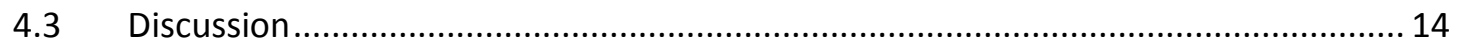

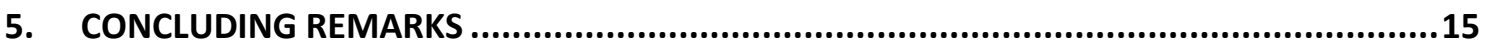

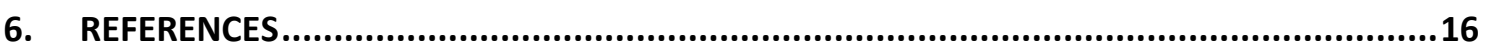

* Instituto Universitário de Lisboa (ISCTE-IUL), BRU-IUL, Lisboa, Portugal. Corresponding author. conceicao.figueiredo@iscte.pt

** Instituto Universitário de Lisboa (ISCTE-IUL), DINÂMIA'CET-IUL, Lisboa, Portugal. fatima.suleman@iscte.pt

*** Instituto Universitário de Lisboa (ISCTE-IUL), CIES-IUL, Lisboa, Portugal. maria.botelho@iscte.pt 


\title{
Typology abuse and harassment in domestic work in
} Portugal $^{1}$

\begin{abstract}
Using an original dataset, our study explores types of abuse and harassment suffered by a sample of domestic workers in Portugal $(n=684)$. Empirical evidence based on multiple correspondence and cluster analyses pointed to three segments of domestic workers: victims of labour abuse related to contract and wages, victims of multiple abuse including mistreatment and also psychological and sexual harassment, and a segment with no occurrence of abuse. Descriptive statistics suggest migrants, especially Brazilian women, prevail in all types of abuse and harassment, but carers of the elderly are often victims of multiple abuse. Domestic workers seem to be protected from the risk of mistreatment by trust related issues and child caring.
\end{abstract}

KEYWORDS: Domestic workers; abuse and harassment; informality; migration.

\section{${ }^{1}$ Acknowledgements}

This research was possible thanks to data collected within Domestic Work and Domestic Workers: Interdisciplinary and Comparative Perspectives project granted by FCT - Foundation of Science and Technology, of Ministry of Education and Science PTDC/JUR/65622/2006. We gratefully acknowledge the comments from participants at XI Jornadas de Economía Laboral in Bellaterra, Barcelona, in July 01-03 2015; The Fourth Conference of the Regulating for Decent Work Network, Geneva, 8 -10 July 2015; and CICOT 2015 3rd International Congress on Working Conditions Porto, 10-11 September, 2015. 


\section{INTRODUCTION}

Most of the abuse and harassment of domestic workers is invisible to researchers and policy makers because the workplace is a private house, and the working relationship, especially that of migrants, is often undeclared. In fact, the work of labour inspectors is constrained by the right to privacy as special permission is required to enter a private residence (ILO 2010). While available research highlights the greater vulnerability of migrants (e.g. Huling 2011; Cruz and Klinger 2011), it has not adequately explored other factors that affect the probability of violence in the workplace or that reduce this risk.

This study uses dedicated data from a survey of domestic workers in Portugal $(n=684)$ and analyses the different kinds of mistreatment suffered by domestic workers. Following the available literature that discriminates different types of abuse (e.g. Bakan and Stasiulis 1997), we use multiple correspondence and cluster analysis to classify the abuse and harassment reported by the sampled domestic workers. Next, the study examines socio-demographic and employment characteristics associated with each type of abuse and harassment.

Despite some references to mistreatment in the literature, systematic research is needed to enhance our understanding of the type of abuse in Portugal; domestic work in this country is sought by both native and migrant women and labour legislation was defined many years ago. Recently, the Portuguese government ratified the ILO Convention 189 (Parliament Resolution 42/2015) and it is expected to implement these recommendations; national bodies have actively strived to prepare material and disseminate information on legal rights and legislation in domestic work (e.g. GAMI 2012). Our findings for Portugal reveal that domestic workers suffer similar problems to those experienced by their counterparts worldwide and this issue therefore warrants reflection.

The rest of paper is organised as follows. The next section reports literature on abuses and harassments in domestic work. Section 3 describes the methodology and the dataset used in this study. Section 4 is devoted to empirical analysis and discussion of the findings, while section 5 presents some concluding remarks.

DINÂMIA'CET - IUL, Centro de Estudos sobre a Mudança Socioeconómica e o Território

ISCTE-IUL - Av. das Forças Armadas, 1649-026 Lisboa, PORTUGAL

Tel. 210464031 - Extensão 293100 E-mail: dinamia@iscte.pt http://dinamiacet.iscte-iul.pt/ 


\section{VIOLENCE IN PRIVATE HOUSEHOLDS}

\subsection{Abuse and harassment in domestic work}

Violence in the workplace includes a variety of hostile behaviours that affect workers irrespective of their gender or occupation. The victims of mistreatment often lack power in their employment relationship, have limited protection or job alternatives (Chappell and Martino 2006). This is certainly the case of domestic work in which non-family members, usually women and migrants, perform household tasks such as housekeeping and caring (Moya 2007).

Literature shows that mistreatment is common in domestic work. It is quite impossible to examine the activity without addressing or detailing the disadvantages of domestic work and addressing the different kinds of abuse and mistreatment suffered by domestic workers (e.g. Arat-Koc 1989; Glenn 1992; Bakan and Stasiulis 1997; Parrenãs 2000; Anderson 2004; Burnham and Theodore 2012). Workplace violence in domestic work can be categorised as type $\mathrm{II}^{2}$ (Merchant and Lundell, 2001), where the perpetrator is usually the care receiver and the violence occurs during the work-related interaction. Domestic workers belong to a high-risk group for gender-based violence (Cruz and Klinger 2011).

Scholarly research as well as the press and reports from international institutions document the various types of abuse suffered by domestic workers worldwide (e.g. Bakan and Stasiulis 1997; Burnham and Theodore 2012; ILO 2013). Bakan and Stasiulis (1997) use the label of 'labour abuses' to describe the mistreatment associated with wages and contracts. They report the non-payment of wages, wages in arrears, underpayment of wages, excessive working hours, non-payment of overtime, and breach of contractual agreements. However, other less explicit abuse also occurs in domestic work.

For example, employers underline their superiority by developing maternalist relationships with their domestic workers (Rollins 1985). Gifts are sometimes given as an act of kindness, benevolence or to demonstrate care for domestic workers (Bakan and Stasiulis 1997); they may be old and second hand clothes, furniture and gadgets, and left-over food. However, these 'gifts' are substitutes for benefits or higher wages (Romero 1992). Employers often define spatial arrangements, such as separate entrances, separate stairwells, outdoor toilets (Lan 2003) to emphasis the inferiority of domestic workers.

\footnotetext{
2 The authors propose four categories of workplace violence: type I, there is no relationship between perpetrator and the victim; type II, where care receiver is the perpetrator; type III where the violence occurs among workers; and type IV where perpetrator has a personal relationship with the victim (Merchant and Lundell, 2001).
} 
Furthermore, domestic workers are sometimes victims of more severe abuse and harassment. Reports of mistreatment refer to verbal, psychological, physical and sexual abuse and harassment, including rape (Bakan and Stasiulis 1997; Burnham and Theodore 2012); forced labour (Hulling 2011); the obligation to live in the employer's house (Lin 1999); imprisonment in employer's house (Jureidini and Moukarbel 2004); the control of food consumed (Lan 2003), that is, employers define the quantity and quality of food available for domestic workers; and substandard accommodation in the case of live-in workers (Arat-Koc 1989; Bakan and Stasiulis 1997).

Empirical evidence suggests that migrant domestic workers are severely mistreated and exploited worldwide ${ }^{3}$, though especially in some countries, and are often more discriminated than their native-born counterparts. Huling (2011) focuses on the forced labour of Indonesian migrants in Malaysia and states that unregulated employment relationships make these workers vulnerable to human trafficking. Lin (1999) reports unequal treatment of migrant and native domestic workers in Taiwan. Whereas the former are obliged to live in their employer's home in Taiwan, native workers tend to be part-time cleaners, earn higher wages and benefit from greater flexibility and autonomy. Lan (2003) also draws attention to the marginalisation of migrant workers in Taiwan, which reflects class and ethnic stratification, and the spatial segregation. Chappell and Martino (2006) describe the fear of deportation among African workers in Egypt that heightens their risk of being victims of violence; they also note the lack of labour law covering domestic workers in Saudi Arabia. Singapore imposes restrictions on marriage and cohabitation with Singaporeans or permanent residents, and on giving birth (Bakan and Stasiulis 1997). Under the label of 'contract slavery', Jureidini and Moukarbel (2004) report abuses against temporary Sri Lankan migrant workers in the Lebanon.

However, even countries with more liberal regimes and favourable conditions for migration such as Canada are not without various types of abuse (Bakan and Stasiulis 1997). Anderson (2004) reports that migrant domestic workers in the UK are vulnerable to physical, psychological and sexual violence, while Burnham and Theodore (2012) note similar mistreatment in the US. The authors stress that employers in the US also fail to provide benefits, pay social security contributions, overtime, or to allow time for rest and sufficient sleep. Bakan

3 For detailed examples of those conditions see Human Right Watch: http://www.hrw.org/search/apachesolr search/domestic\%20worker. There are additional complaints on how employers benefit from the lack of regulations in the domestic workers labour market (e.g. http://apirnet.ilo.org/news/some-employers-take-advantage-of-weak-legal-protection-walls-at-every-turnfor-domestics).

DINÂMIA'CET - IUL, Centro de Estudos sobre a Mudança Socioeconómica e o Território ISCTE-IUL - Av. das Forças Armadas, 1649-026 Lisboa, PORTUGAL

Tel. 210464031 - Extensão 293100 E-mail: dinamia@iscte.pt http://dinamiacet.iscte-iul.pt/ 
and Stasiulis argue that domestic workers face abuse everywhere in the world and that the mistreatment differs in degree rather in kind.

The specific situation of live-in domestic workers and how it affects their working conditions is another area of concern. Live-in workers are often isolated from their own families and support systems; are paid low wages despite long working hours (Cruz and Klinger 2011); have little access to phone, mail or internet (Burnham and Theodore 2012); ultimately, they are exploited. Furthermore, the employment relationship and social relations with their employers tend to overlap and they are expected to make sacrifices as if they were part of the family (Bakan and Stasiulis 1997).

Not surprisingly, informal workers are also more vulnerable to abuse. Cox and Watt (2002) detail the benefits of informality for employers; there is no need to give sick or holiday pay, to provide health and safety protection and the worker cannot accuse them of unfair dismissal. Undocumented workers in the US are more likely to have lower wages and poor working conditions (Burnham and Theodore 2012).

In fact, domestic workers, and especially migrants, are often categorised as modern slaves (Anderson 2004) without rights as citizens or workers. The literature suggests that the lack of labour laws protecting domestic workers contributes decisively to the risk of abuse. The evidence reported revealed predictors of abuse and highlights the vulnerability of migrants.

Although the abovementioned literature describes the range of abuses and harassment in domestic work, the mistreatment has not yet been systematically categorised. To the authors' knowledge, only the study by Bakan and Stasiulis (1997) has gone further in terms of categorisation, labelling abuses related to wages and contracts as 'labour abuses'.

\subsection{Abuse and harassment in domestic work in Portugal}

As for other countries worldwide, no systematic analysis has as yet been made of the abuse and harassment suffered by domestic workers in Portugal. This warrants attention because there is a growing demand for domestic workers due to employment patterns, demographic issues, and a familialist society. Portugal has the highest rate of female employment in Southern Europe, with women continuing to work even after they start a family (Casaca 2013). Moreover, Casaca insists that women have long working hours and that part-time jobs are scarce.

The Portuguese labour market is attractive to migrants, especially from Portuguese speaking ex-colonies and European countries (Abrantes 2012); like native women, they see domestic work as a job opportunity because the poor provision of state care means these services are in demand (Leitner 2003). Families have to resolve care issues privately by hiring domestic workers to look after the elderly or disabled at home (São José 2012); in fact, private 
households are the largest employers of care workers (Oso and Catarino 2013; Cangiano 2014). It is thanks to domestic workers that many women have been able to reconcile work and family life and to maintain the labour division within families (Crompton 2006) at a low cost (Torres 2008).

Domestic workers in Portugal enjoy the same access to legal and social protection as other employees. Social protection was extended to domestic workers in the late 1960s before the end of the fascist regime, and the respective labour legislation dates back to the 1980s and 1990s. Decree-law 235/92 sets out the working conditions employers must provide and it covers the tasks to be performed, pay and pay components including paid holidays and Christmas bonus, among others. Furthermore, domestic workers are entitled to the national minimum wage and social security contributions are compulsory (for more details on legal rights see Suleman 2015).

The literature on abuse and harassment is limited. Pereira (2013) reports low pay, long working hours and greater vulnerability of migrants. Abrantes (2012) notes the violation of labour rights, namely non-payment of Christmas and holiday bonuses, non-provision of maternity leave, and non-payment of health care in cases of work accidents. Employers foster the informality that pervades domestic work and Abrantes recognises that they are unwilling to declare the employment relationship to social security and pay the respective contributions.

Despite scarce literature, newspapers and online blogs provide reports of mistreatment and violations of legal rights. They also reveal discrimination on the grounds of colour and social origin. Like the evidence of Jureidini and Moukarbel (2004) on racial hierarchy in Lebanon, Gomes (2012) refers to the employers' perceptions of different social origins when hiring a worker in Portugal: Africans are considered more docile, Brazilians more sensual, and Eastern European more educated. Pereira (2013) identified a preference for the latter not only because they have better qualifications, but also for their learning ability and work discipline. On the other hand, Africans are thought to accept lower wages and long working hours.

Domestic workers express concern about having to perform whatever task they are asked to do, including taking care of animals, and about the employer being able to terminate the employment relationship without any legal repercussions (Gomes 2012). Migrants recognise that the employment relationship in domestic work is governed by a colonial mentality.

The literature has also devoted scant attention to sexual and psychological harassment. Once again, the press and migrant aid agencies in Portugal are an important source of data about this. 'Comunidária"4 - a migrant aid agency - receives around two hundred complaints of

\footnotetext{
${ }^{4}$ http://www.comunidaria.org/conhecer.php.

DINÂMIA'CET - IUL, Centro de Estudos sobre a Mudança Socioeconómica e o Território ISCTE-IUL - Av. das Forças Armadas, 1649-026 Lisboa, PORTUGAL

Tel. 210464031 - Extensão 293100 E-mail: dinamia@iscte.pt http://dinamiacet.iscte-iul.pt/
} 
harassment a year. Most of these refer to psychological harassment (90\%), as victims are ashamed or afraid to report cases of sexual harassment. The few statements on the latter come from Brazilian workers and indicate that live-in workers are more vulnerable and that employers make sexual favours a condition for a formal contract. The data suggest that there are not only preconceptions about different social origins but that these might be associated with particular kinds of abuse. The evidence reported sheds light on the vulnerability of migrants. Reyneri (2003), Gomes (2012) and Pereira (2013) also note that informality, undeclared work and illegal migration contribute to perpetuating unfavourable conditions.

\section{DATA AND METHODOLOGY}

\subsection{The dataset}

The empirical analysis draws on an original cross-sectional dataset of domestic workers in Portugal collected in 2010 for an international project (see Guibentif 2011 for details). Given the characteristics of domestic workers and their workplace, snowball sampling was used to gain access to participants. The contact details of domestic workers were obtained from domestic work unions, immigration-related institutions, and personal acquaintances.

The data were gathered in face to face interviews and includes information on sociodemographic characteristics, demand for skills, wages, contracts, tasks to be performed, working hours, formality, trust-related issues and employers' characteristics $(n=684)$.

Though some variables are self-explanatory, others deserve further explanation. For instance, workers' statements were the source of data about the abuse experienced. The sampled workers gave yes/no responses to whether they had experienced one or more of the following situations: wages in arrears, unpaid allowances, unpaid overtime, unpaid social security contributions; obligation to perform tasks not in the initial agreement, deprivation of rest time, deprivation of food, deprivation of holidays, sexual harassment, physical violence, psychological harassment, discrimination, obligation to perform tasks against will and spatial segregation. The respondents were also asked if they received gifts from employers and, if so, what kind of gift.

The information about contractual arrangements was obtained from yes/no answers about the existence of a written employment contract, the payment of social security and income tax and the payment system including hourly, daily or monthly contracts. In addition, respondents reported if they worked for just one or several employers and whether they were live-in or live-out workers. 
The tasks performed were collected from a list of 19 items detailing the specific cleaning, cooking, child and elderly care tasks. Domestic workers were recoded into three types of job: cleaners, child caregivers, and elderly care workers.

Trust issues were addressed in three questions: whether employers asked for references; whether workers were entrusted with the key to the house; and how work was monitored. Monitoring activities were assessed through the presence (absence) of the employer in the workplace during working hours. Finally, the employers' characteristics were collected through the type of house (flat or house), and the gifts to domestic workers were used to ascertain the type of employment relationship. Table 1 reports statistics of the variables examined in empirical analysis.

Table 1. Descriptive statistics [mean, (SD)]

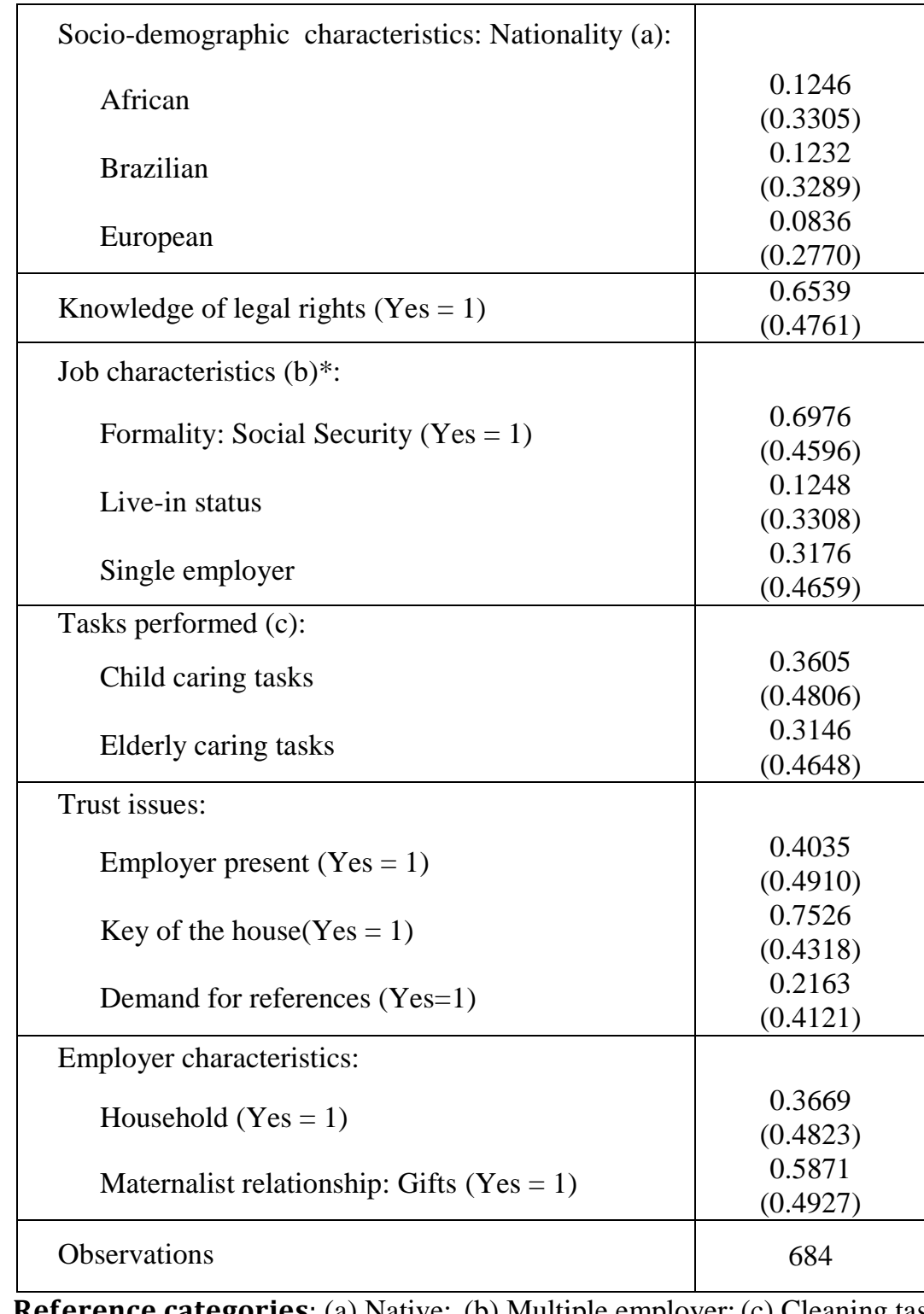

Reference categories: (a) Native; (b) Multiple employer; (c) Cleaning tasks. 


\subsection{Constructing typologies: multiple correspondence and cluster analysis}

We use multiple correspondence analysis (MCA) and cluster analysis (CA) to explore typologies of abuse in domestic work. Guibentif (2011) was the first to address these typologies using a principal component analysis (PCA) to ascertain types of abuse. His analysis is descriptive however and does not offer a systematic picture of the violence at work. Moreover, PCA is questionable as a method to explore discrete data.

Our analysis of typologies is developed in two steps. We first apply an MCA to our discrete data on abuses to detect and represent the relationship among variables. Secondly, we apply a CA to validate the perceived profiles obtained from the MCA.

\section{EMPIRICAL EVIDENCE}

\subsection{Typologies of abuse in domestic work}

The application of the Multiple Correspondence Analysis (MCA) to our categorical data led to two dimensions. The first shows the associations between the categories of workers who stated they were not a victim of abuse, as opposed to those who said they were. The second dimension indicates different types of abuse.

The spatial distribution of categories shows the first dimension (occurrence of abuse and harassment) in the horizontal axis and illustrates no abuse versus the presence of abuse; the different types of abuse associated with the second dimension are defined in the vertical axis which is labelled types of abuse. The first quadrant depicts the association between several forms of psychological and physical violence. The types of abuse in the fourth quadrant are mostly related to wage and contracts. The second and third quadrants group the 'No' categories, meaning no abuse. In light of this distribution, it seems logical to consider the three profiles illustrated in Figure 1, which displays the projection of these dimensions.

DINÂMIA'CET - IUL, Centro de Estudos sobre a Mudança Socioeconómica e o Território ISCTE-IUL - Av. das Forças Armadas, 1649-026 Lisboa, PORTUGAL 
Figure 1. Spatial distribution of the risk of abuse

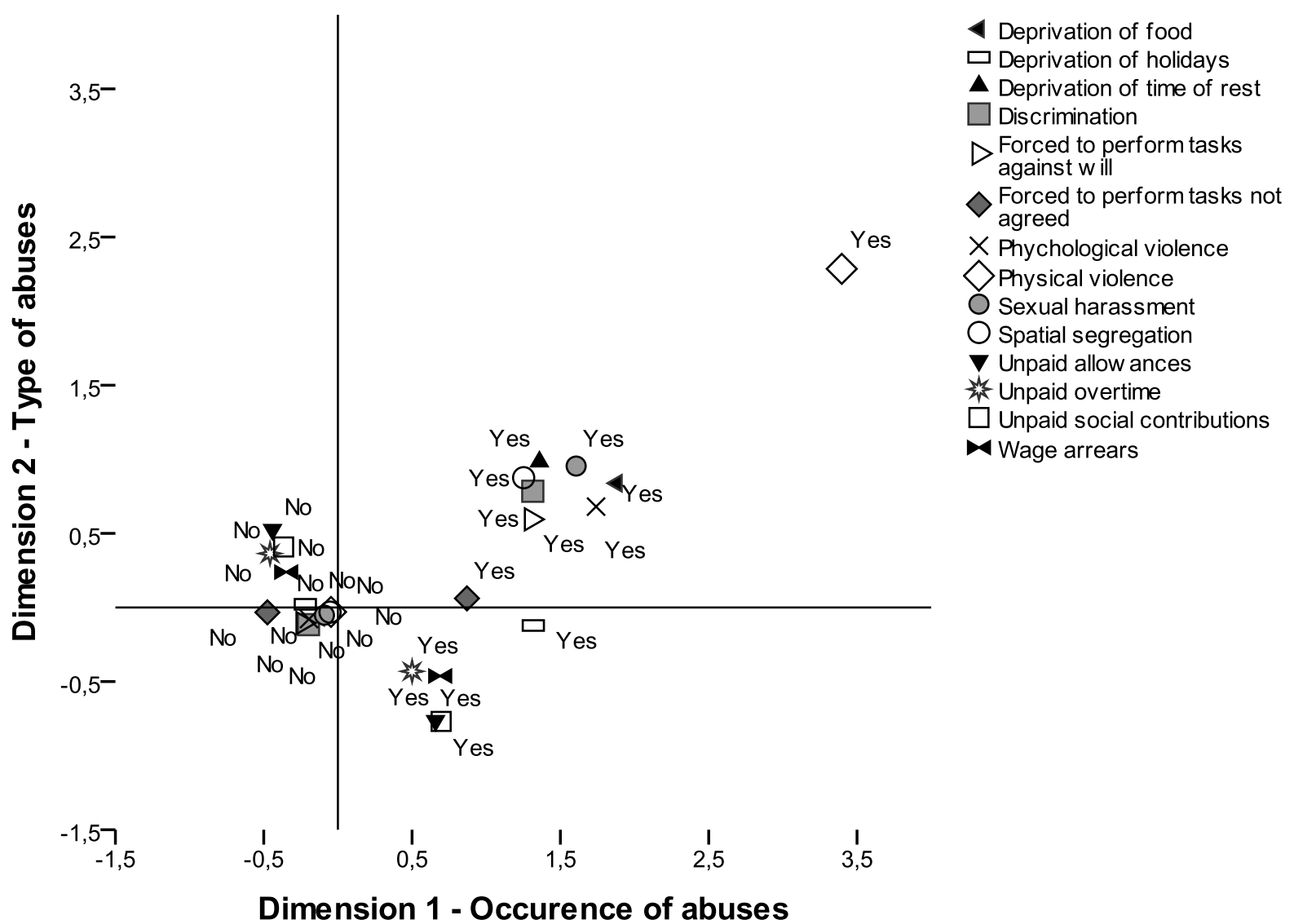


The second step consisted of a cluster analysis (CA), hierarchical and K-means, to validate the segments perceived through MCA. Cluster analysis confirmed the segmentation of domestic workers in the sample in three clusters, which we labelled as: 'multiple abuse', 'no abuse' and 'labour abuses'. Table 2 reports the specific types of abuse aggregated in each.

Table 2. Types of abuses suffered by domestic workers

\begin{tabular}{|l|c|c|c|}
\hline \multicolumn{1}{|c|}{} & $\begin{array}{c}\text { Multiple } \\
\text { abuses } \\
(\mathrm{n}=96 ; 14.0 \%) \\
\text { \% of Yes }\end{array}$ & $\begin{array}{c}\text { No abuses } \\
(\mathrm{n}=354 ; 51.8 \%) \\
\text { \% of Yes }\end{array}$ & $\begin{array}{c}\text { Labour abuses } \\
(\mathrm{n}=234 ; 34.2 \%) \\
\% \text { of Yes }\end{array}$ \\
\hline Wage arrears & 49.0 & 14.2 & 56.8 \\
Unpaid allowances & 44.8 & 6.3 & 90.1 \\
Unpaid overtime & 61.5 & 26.4 & 72.4 \\
Unpaid social contributions & & 6.6 & 75.3 \\
Forced to perform tasks not agreed & 86.5 & 14.0 & \\
Deprivation of time of rest & 67.7 & 2.3 & \\
Deprivation of food & 28.3 & 1.2 & \\
Deprivation of holidays & 41.7 & 2.0 & \\
Sexual harassment & 22.9 & 1.7 & \\
Physical violence & 9.5 & 0.0 & \\
Psychological violence & 45.7 & 1.7 & \\
Discrimination & 52.1 & 5.4 & \\
Forced to perform tasks against will & 59.4 & 5.1 & \\
Spatial segregation & 14.7 & 1.7 & \\
\hline
\end{tabular}

The descriptive analysis has already shown that labour abuses were the most common type of abuse in our sample. The estimated clusters suggest the presence of a non-negligible proportion of domestic workers reporting no abuse (51.8\%), while the segment of multiple and more severe abuse affects a small proportion of the sampled workers. 


\subsection{Domestic workers and job characteristics}

The results from descriptive statistics illustrate that socio-demographic and job characteristics vary in line with the types of abuse (Table 3 ).

Table 3. Domestic workers in each type of abuse and harassment

\begin{tabular}{|l|r|r|r|}
\hline & $\begin{array}{c}\text { Multiple } \\
\text { abuses }\end{array}$ & No abuses & \multicolumn{1}{c|}{$\begin{array}{c}\text { Labour } \\
\text { abuses }\end{array}$} \\
\hline Nationality: & & & \\
African & $8.3 \%$ & $14.8 \%$ & $10.7 \%$ \\
Brazilian & $21.9 \%$ & $7.7 \%$ & $15.4 \%$ \\
European & $12.5 \%$ & $6.8 \%$ & $9.0 \%$ \\
Native & $57.3 \%$ & $70.7 \%$ & $65.0 \%$ \\
\hline Job characteristics: & & & \\
Formality: social security (Yes =1) & $71.9 \%$ & $73.4 \%$ & $63.5 \%$ \\
Live-in status (Yes = 1) & $20.0 \%$ & $12.7 \%$ & $9.0 \%$ \\
Single employer (Yes = 1) & $36.2 \%$ & $33.7 \%$ & $27.0 \%$ \\
Child caring tasks (Yes = 1) & $20.9 \%$ & $35.2 \%$ & $42.2 \%$ \\
Elderly caring tasks (Yes =1) & $38.8 \%$ & $28.7 \%$ & $33.2 \%$ \\
\hline Trust issues: & & & \\
Employer present (Yes = 1) & $44.1 \%$ & $40.2 \%$ & $39.1 \%$ \\
Key of the house (Yes = 1) & $68.4 \%$ & $80.7 \%$ & $69.7 \%$ \\
Demand for references (Yes =1) & $19.4 \%$ & $16.8 \%$ & $29.5 \%$ \\
\hline Employer characteristics: & & & \\
Household (Yes = 1) & $47.4 \%$ & $37.8 \%$ & $30.6 \%$ \\
Maternalist relationship: Gifts (Yes =1) & $61.5 \%$ & $64.9 \%$ & $48.3 \%$ \\
\hline
\end{tabular}

The estimates reported in Table 3 indicate that migrants are more vulnerable to all type of abuses. Brazilian workers prevail in both types of abuses; European workers are often victim of multiple abuses (12.5\%); while Africans (10.7\%) are more likely in labour abuses. Additionally, carers of the elderly and those working in detached houses are more vulnerable to all types of abuse. On the other hand, domestic workers performing child care tasks are less likely to suffer from multiple abuse. In addition, trust related issues, represented by having a key to the house, lower the probability of this type of abuse ( $80.7 \%$ in no abuses). It has to be noted that workers engaged in maternalist relationship with their employers prevail in multiple but also in no abuse clusters. 


\subsection{Discussion}

The results obtained so far provide the literature with further evidence of the variety of abuse experienced by domestic workers in their workplace (Bakan and Stasiulis 1997). Our typology of abuses discriminated between multiple and labour abuse, but also included a cluster of workers that had not been victims. It should be stressed that a non-negligible proportion of workers $(51.8 \%)$ reported no abuse in the workplace. Furthermore, the smallest group in the sample is the cluster that includes violation of contractual agreements, notably doing additional tasks or against the worker's will; lack of food; sexual harassment; psychological violence; and discrimination. In other words, a small group of domestic workers in Portugal were victims of severe abuse. Overall, employers tend to delay payment or force domestic workers to do tasks that were not part of the initial agreement. The results obtained so far suggest that Portugal differs in the degree and kind of abuse suffered by domestic workers.

The descriptive estimates highlight migrant domestic workers' vulnerability to more severe abuse (Huling 2011; Lin 1999). In addition, we find that migrant workers are not all mistreated in the same way. The estimates show that African domestic workers tend to suffer labour abuses, and that Brazilian workers are the most vulnerable. A racial hierarchy was an additional source of discrimination against migrant workers, as reported in other countries where migrants from different countries compete for jobs in domestic work (Jueridin and Moukarbel 2004). The results clearly pointed to a 'triple' prejudice that domestic workers come up against, namely women, migrant and Brazilian migrants.

Our results corroborate the statements of Brazilian migrants on their vulnerability to severe abuse (in the "Comunidária" online site). Moreover, Gomes (2012) showed that employers perceive Brazilian women to be sensual. The estimates suggest an association between this perception and the likelihood of being a victim of multiple abuse including sexual abuse and harassment.

Like previous studies (e.g. Cruz and Klinger 2011), our evidence suggests higher vulnerability of live-in workers, whereas the individual data provide accounts of live-in workers having to be on call 24 hours a day. In addition, a colonial mentality in the management of livein workers is reported in Portugal (Gomes 2012).

However, these workers tend to care for the elderly and, according to our estimates, they are in fact vulnerable to multiple abuse. In other words, the perpetrator might be the receiver of care and the abuse occurs during work-related interaction (Merchant and Lundell 2001). Nevertheless, domestic workers recognise that this behaviour may be due to mental health issues and therefore excuse it (Gomes 2012).

DINÂMIA'CET - IUL, Centro de Estudos sobre a Mudança Socioeconómica e o Território ISCTE-IUL - Av. das Forças Armadas, 1649-026 Lisboa, PORTUGAL

Tel. 210464031 - Extensão 293100 E-mail: dinamia@iscte.pt http://dinamiacet.iscte-iul.pt/ 


\section{CONCLUDING REMARKS}

Substandard working conditions and mistreatment are pervasive in domestic work worldwide. These conditions reflect some of the structural disadvantages of domestic work, notably for migrant women and especially informal workers. The lack of regulations has also played a key role in perpetuating poor working conditions. The aim of our study was to classify the abuses experienced by a sample of domestic workers in Portugal and then explore the predictors of each type of abuse and harassment.

Empirical evidence indicated three clusters of workers, namely those who had experienced no abuse, victims of multiple abuse and victims of labour abuses. Whereas the latter involve wages and contractual issues, multiple abuse is a more severe type of workplace violence which thankfully affects only a small group in our sample. The most recurrent abuse is due to financial constraints that ultimately determine employers' management of domestic workers in Portugal.

The findings suggest higher vulnerability of migrant workers, especially from Brazil, that suffer all types of abuses, including the severe ones. Additionally, descriptive statistics provide evidence on the prevalence of live-in workers in multiple abuses as well as of the elderly carers and live-in domestic workers.

Our sample is small and based on snowball sampling and therefore far from random. However, this sampling method is suitable for this particular labour market as it gives us access to illegal situations.

Despite the social and political relevance of our empirical evidence, all results must be regarded with circumspection. Nevertheless, a distinction should be made between the very severe abuse documented in other countries and the abuse described by domestic workers in Portugal. Further research is required to cluster countries according to the degree, kind and frequency of abuse as it would help policy makers to set appropriate regulations.

DINÂMIA'CET - IUL, Centro de Estudos sobre a Mudança Socioeconómica e o Território ISCTE-IUL - Av. das Forças Armadas, 1649-026 Lisboa, PORTUGAL 


\section{REFERENCES}

ABRANTES, M. (2012), "A densidade da sombra. Trabalho doméstico, género e imigração.” Sociologia, Problemas e Práticas LXX, pp. 91-110.

ANDERSON, B. (2004), "Migrant Domestic Workers and Slavery1.” In The Political Economy of New Slavery edited by Christien van den Anker, 107. Palgrave Macmillan Ltd.

ARAT-KOC, S. (1989), "In the Privacy of our own Home: Foreign Domestic Workers as Solution to the Crisis in the Domestic Sphere in Canada." Studies in Political Economy XXVIII, pp. 33-58.

BAKAN, A.B., Stasiulis, D.K. (1997), Not One of the Family: Foreign Domestic Workers in Canada. University of Toronto Press.

BURNHAM, L., Theodore, N. (2012), Home Economics. The Invisible and Unregulated World of Domestic Work. National Domestic Workers Alliance, New York, NY.

CANGIANO, A. (2014), "Elder care and migrant Labor in Europe: a demographic outlook. "Population and Development Review XL(1), pp. 131-154.

CASACA, S.F. (2013), “As novas dinâmicas laborais e os desafios da articulação com a vida familiar." Sociologia, Problemas e Práticas LXXII, pp. 31-52.

CHAPPELL, D., Di Martino, V. (2006), Violence at work. International Labour Office, Geneve, $3^{\text {rd }}$ edition.

COX, R., Watt, P. (2002), "Globalization, polarization and the informal sector: the case of paid domestic workers in London.” Area XXXIV (1), pp. 39 - 47.

CROMPTON, R. (2006), Employment and the Family. The Reconfiguration of Work and Family Life in Contemporary Societies. Cambridge: Cambridge University Press.

Cruz, A., Klinger, S. (2011), Gender-based violence in the world of work: Overview and selected annotated bibliography. International Labour Office, Geneve.

DINÂMIA'CET - IUL, Centro de Estudos sobre a Mudança Socioeconómica e o Território ISCTE-IUL - Av. das Forças Armadas, 1649-026 Lisboa, PORTUGAL

Tel. 210464031 - Extensão 293100 E-mail: dinamia@iscte.pt http://dinamiacet.iscte-iul.pt/ 
GAMI (2012), Direitos e Deveres no Trabalho Doméstico, Lisbon: GAMI, Lisbon, http:|lwww.solimigrante.org/wp-content/uploads/2012/04/Brochura-Direitos-e-

Deveres final2.pdf.

GLENN, E.N. (1992), "From Servitude to Service Work: Historical Continuities in the Racial Division of Paid Reproductive Labor.” Signs, XVIII(1), pp.1- 43.

GOMES, C. (2012), "O invisível mundo dos abusos contra as trabalhadoras domésticas." Público, http://www.publico.pt/portugal/jornal/o-invisivel-mundo-dos-abusos-contra-astrabalhadoras-domesticas-24626828

GUIBENTIF, P. (2011), Rights perceived and practiced - Results of the survey carried out in Portugal as part of the project: "Domestic Work and Domestic Workers Interdisciplinary and Comparative Perspectives". Working Paper Dinâmia'CET-IUL 143, Lisboa, Instituto Universitário de Lisboa.

HULING, A. (2011), "Domestic Workers in Malaysia: Hidden Victims of Abuses and forced Labor.” International Law and Politics, XLIV, pp. 629- 680.

ILO (2010), Decent work for domestic workers Fourth item on the agenda. International Labour Office, Geneva.

ILO (2013), Domestic workers across the world: global and regional statistics and the extent of legal protection. International Labour Office, Geneva.

JUREIDINI, R., MOUKARBEL, N. (2004), "Female Sri Lankan domestic workers in Lebanon: a case of 'contract slavery'?” Journal of Ethnic and Migration Studies, XXX (4), pp. 581-607.

LAN, P.C. (2003), "Political and Social Geography of Marginal Insiders: Migrant Domestic Workers in Taiwan." Asian and Pacific Migration Journal XXII (1-2), pp. 99-125.

LEITNER, S. (2003), "Varieties of familialism: The caring function of the family in comparative perspective.” European Societies V (4), pp. 353-375.

LIN, C.J. (1999), Filipina Domestic Workers in Taiwan: Structural Constraints and Personal Resistance. Taipei: Taiwan Grassroots Women Workers' Centre.

DINÂMIA'CET - IUL, Centro de Estudos sobre a Mudança Socioeconómica e o Território ISCTE-IUL - Av. das Forças Armadas, 1649-026 Lisboa, PORTUGAL

Tel. 210464031 - Extensão 293100 E-mail: dinamia@iscte.pt http://dinamiacet.iscte-iul.pt/ 
MERCHANT, J.A., Lundell, J.A. (2001), "Workplace violence intervention research workshop: Background, rationale and summary." American Journal of Preventive Medicine XX (2), pp. 135-140.

MORAS, A.( 2008), "The private home as a public workplace: employing paid domestic labour.2 Journal Workplace Rights XIII (4), pp. 377-400.

MOYA, J.C. (2007), "Domestic service in global perspective: gender, migration and ethnic niches.” Journal of Ethnic and Migration Studies XXXIII (4), pp. 559-579.

OSO, L., Catarino, C. (2013), "From Sex to Gender: The Feminisation of Migration and Labour-Market Insertion in Spain and Portugal." Journal of Ethnic and Migration Studies XXXIX (4), pp. 625-647.

PARREÑAS, R. 2005. "Long distance intimacy: class, gender and intergenerational relations between mothers and children in Filipino transnational families." Global Networks 5 (4): 317 336.

Pereira, S. 2013. "Replacement migration and changing preferences: immigrant workers in cleaning and domestic services in Portugal." Journal of Ethnic and Migration Studies 39 (7): $1141-1158$.

REYNERI, E. 2003. "Immigration and the underground economy in new receiving South European countries: manifold negative effects, manifold deep-rooted causes." International Review of Sociology: Revue Internationale de Sociologie 13 (1): 117-143.

ROLLINS, J. 1985. Between women: domestic and their employers. Philadelphia, Temple University Press.

ROMERO, M. 1992 . Maid in U.S.A. Routledge, N.Y.

SÃO JOSÉ, J. 2012. “A divisão dos cuidados sociais prestados a pessoas idosas Complexidades, desigualdades e preferências.2 Sociologia, Problemas e Práticas 69: 63-85.

SULEMAN, F. 2015. "The employment relationship in an (almost) structureless labour market: the case of domestic work." Cambridge Journal of Economics. doi: 10.1093/cje/beu018

TORRES, A.C. 2008. "Women, gender and work: the Portuguese case in the context of the European Union.” International Journal of Sociology 38(4): 36-56.

DINÂMIA'CET - IUL, Centro de Estudos sobre a Mudança Socioeconómica e o Território ISCTE-IUL - Av. das Forças Armadas, 1649-026 Lisboa, PORTUGAL

Tel. 210464031 - Extensão 293100 E-mail: dinamia@iscte.pt http://dinamiacet.iscte-iul.pt/ 